\title{
Muslim Sermons in Russian: Communicative and Pragmatic Aspect
}

\section{Itskovich Tatiana Viktorovna ${ }^{1}$}

Professor, Ural Federal University named after the first President of Russia B.N.

Yeltsin,

Yekaterinburg, Russia.

\section{Tugolbaigizi Ajamal ${ }^{2}$}

Master of Philology of the Department of Russian Language, Ural Federal

University named after the first President of Russia B.N. Yeltsin,

Yekaterinburg, Russia.

(date of receiving: February, 2019; date of acceptance: June, 2019)

\begin{abstract}
Most of Russian researches in the field of religious communication are devoted to Christianity, other traditional religions rarely become the object of linguists' attention. The object of this study is the genre of Islamic preaching, functioning in Russian. In Muslim sermon is understood as the solemn moral speech of the Imam-Khatib, dedicated to an Islamic religious or moral-ethical issue. The recipient of the Muslim sermon is the Imam-Khatib, who must have a knowledge of the Islam fundamentals, be well educated, and know the prototext of the Quran well. Besides the Quran, the preacher also addresses contemporary material, includes cautionary life stories in a sermon, and concerns current social problems. The addressee of Muslim sermon has several distinguishing features: pronounced a sermon in the mosque and meant for faithful men, it is a compulsory element of religious life. A woman in Islam occupies a special position, she is not forbidden to visit the mosque, but it is recommended to pray at home. There is a socalled sermon at home in Muslim, which is pronounced as Imam-Khatib for women, as well as religiously educated woman.
\end{abstract}

Keywords: Religious Functional Style, Islam, Sermon, Communicative and Pragmatic Aspect, Addresser, Addressee.

1. E-mail: tatiana.itckovich@urfu.ru

2. E-mail: aijamal_1808@mail.ru 


\title{
Мусульманские проповеди на русском языке:
}

\section{коммуникативно-прагматический аспект}

\author{
Ицкович Татьяна Викторовна ${ }^{1}$ \\ Профессор, Уральский федеральный университет им. первого Президента \\ России Б.Н. Ельцина, \\ Екатеринбург, Россия \\ Туголбайкызы Айжама. ${ }^{2}$ \\ Магистр филологии, Уральский федеральный университет им. первого \\ Президента России Б.Н. Ельцина, \\ Екатеринбург, Россия. \\ (дата получения: февраль 2019 г.; дата принятия: июнь 2019 г.)
}

\begin{abstract}
Аннотация
Большинство российских исследований в области религиозной коммуникации посвящены христианству, другие традиционные конфессии редко становятся объектом внимания лингвистов. Объектом исследования в статье является жанр исламской проповеди, функционирующий на русском языке. В мусульманстве под проповедью понимается торжественная нравоучительная речь имама-хатыба, посвященная религиозной или морально-этической проблеме. Адресантом мусульманской проповеди является имам-хатыб, который должен обладать знаниями основ ислама, быть всесторонне образованным, хорошо знать прототекст Корана. Проповедник обращается также к современному материалу, к жизненным историям, касается актуальных социальных проблем. Адресат проповеди имеет ряд особенностей: проповедь произносится в мечети, предназначена для верующих мужчин, является для них обязательным элементом религиозной жизни. Женщина в исламе занимает особое положение, ей не запрещается посещать мечеть, но рекомендуется молиться дома. В мусульманстве существует так называемая проповедь на дому, которую для женщин произносит как имам-хатыб, так и религиозно образованная женщина.

Ключевые слова: Религиозный Функциональный Стиль, Ислам, Проповедь, Коммуникативно-Прагматический Аспект, Адресант, Адресат.

1. E-mail: tatiana.itckovich@urfu.ru

2. E-mail: aijamal_1808@mail.ru

Исследование выполнено при финансовой поддержке РФФИ в рамках научного проекта №18-012-00382 А «Речевой быт семьи: аксиологическая реальность и методы исследования (на материале живой речи уральского города)».
\end{abstract}




\section{Введение}

Религиозный стиль, выделение и функционирование которого обусловлено такими экстралингвистическими факторами, как специфические формы общественного сознания (религия) и человеческой деятельности, является объектом изучения современной лингвистики. Происходит описание отдельных жанров: исповедь, молитва, акафист, проповедь, житие (Войтак 2003, Прохватилова 1999, Людоговский 2015, Истомина 2013).

Описание религиозного стиля происходит на материале христианских текстов. В то же время в России действуют и другие традиционные конфессии, коммуникация в которых происходит на русском языке. Мусульманство в России является вТорой по величине конфессией после христианства. В мусульманстве религиозные тексты функционируют не только на традиционном для этой конфессии арабском языке, но и на русском. Изучение российскими лингвистами религиозной коммуникации в исламе только начинается (Бобырева 2015, 2016; Бугаева 2016).

\section{Основная часть}

Сфера религиозной коммуникации характеризуется использованием двуязычия: сакральный и обыденный языки, в разное время по-разному деля сферы и функции, уживаются в религиозной коммуникации (Унбегаун 1971, Успенский 1994). В православии в качестве сакрального, богослужебного языка традиционно используется церковнославянский, в исламе - арабский, в иудаизме - иврит. Наряду с сакральными языками в каждой из традиционных религий активно функционирует второй, народный язык. Сакральный язык изначально выполняет богослужебную функцию, на нем написаны священные тексты, читаются молитвы в церкви. Народный язык выполняет миссионерскую фунцию, на нем произносятся проповеди; он используется в ситуации неофициального религиозного общения: на нем строятся личные молитвы верующих. 
В России сегодня официально утверждены четыре традиционные конфессии: христианство, ислам, буддизм, иудаизм. В каждой из этих религий функционирует сакральный язык, использование которого обусловлено исторически и традиционно. В то же время можно отметить заметную роль в религиозной коммуникации русского языка, на котором в силу исторических причин говорят россияне и который многие из них считают родным независимо от национальности.

Российская специфика состоит в том, что русский язык сегодня стал средством религиозной коммуникации не только в православии, но и в других религиях. Он используется в не свойственных ему ранее религиозных конфессиях: исламе, иудаизме, буддизме, о чем свидетельствует Интернет. Например: «Исламский портал» - уникальный ресурс, где каждый правоверный мусульманин может прочесть исламские проповеди уважаемых имамов на русском и татарском языках» (http://www.islam-portal.ru/imam/85/).

В сегодняшней России можно говорить не только о двуязычии, но и о разноязычии в рамках каждой религиозной конфессии. Сакральный язык как язык богослужения сохраняет свои позиции, профанный функционирует в двух разновидностях: национального и русского языков. Так, в исламе на территории России используется арабский, татарский и русский языки; в иудаизме - иврит, идиш и русский; в буддизме - санскрит, бурятский и русский. Таким образом, русский язык стал средством не только межнационального, межрелигиозного, но и внутрирелигиозного общения в различных конфессиональных сферах.

Приметой современной ситуации в российской религиозной коммуникации является разноязычие, причем русский язык используется как средство неформального общения в небогослужебной ситуации в Русской Православной Церкви, а также в иных традиционных конфессиях; частично 
выполняет функцию богослужебного языка, а также выступает средством межконфессионального общения

Религиозный стиль представлен набором жанров-текстотипов, обладающих функциональной общностью и, в то же время, разнящихся по цели коммуникации и особенностям коммуникативной ситуации. В жанровом ряду религиозного стиля проповедь - один из самых ярких репрезентативных жанров, изучение которого в лингвистике является актуальным (Прохватилова 1999; Салимовский 2005; Истомина 2013).

Проповедь как особый богословский жанр является предметом изучения в гомилетике (под гомилетикой понимается «наука о церковном красноречии, или проповедничестве) (Аверкий 2001. 5). Данный феномен исследуется также в других отраслях гуманитарного знания (в риторике, литературоведении, философии, лингвистике). В риторике пастырское слово трактуется как вид духовного красноречия и рассматривается в ряду других жанров ораторского искусства. Современные литературоведческие исследования жанра проповеди определяют границы жанра средневековой проповеди и ее типологические признаки. Рассматривается проповедь и как религиозного феномен в философско-религиоведческом аспекте. Имеющиеся лингвистические исследования обращены к установлению особенностей отбора и функционирования лексических средств средневековой проповеди; выявлению способов включения чужой речи в проповеднические тексты; определению приемов и средств интонационной и ритмомелодической организации современной проповеди, раскрытию специфики диалогичности литургического слова пастыря (Прохватилова 1999).

Обратимся к существующим жанровым определениям. В общем виде проповедь определяется как «жанр конфессионального общения. Религиозное назидание или наставление, как правило, морально-этического характера, произнесенное или написанное авторитетным лицом - представителем какого- 
либо вероучения перед аудиторией последователей этого вероучения. ... В христианстве проповедью называют наставительную речь, обращенную к прихожанам, которую священник произносит в храме после литургии. Задачей проповеди является сообщение и разъяснения слушателям того или иного положения христианского вероучения) (Иванов 2003. 515). Ближе к риторической точке зрения следующее определение: церковная проповедь «это речь религиозно-назидательного характера, с которой священнослужитель обращается к верующим во время богослужения» (Прохватилова 1999. 123). Проповедь - это «основной жанр церковного красноречия: убеждающее поучительное слово священнослужителя, произносимое с церковного амвона (места перед алтарем) и обращенное к пастве - людям, пришедшим в церковь молиться и воспринимать Слово Божие» (Матвеева 2003. 255). Обратим внимание на то, что в различных определениях отмечается религиозная сфера сознания, в которой реализуется проповедь, реальное место произнесения проповеди, а также поучительный, морально-этический характер данного жанра.

Проповедь как жанр-текстотип представляет большой интерес с точки зрения отражения тенденций современного русского литературного языка. Религиозный стиль характеризуется наличием жестко регламентированных жанров, от которых проповедь существенно отличается. Ее своеобразие - в наибольшей степени авторской свободы. Эту отличительную особенность проповеди в ряду других жанров религиозного стиля ранее отмечал Д.С. Лихачев: «... Различные жанры по-разному относились к проблеме авторской собственности. «Чувство авторства» было различно в жанре проповеди и в жанре летописи, в жанре послания и в жанре повести. Первые предполагают индивидуального автора и часто подписывались именами своих авторов, а при отсутствии данных об авторе приписывались тому или иному авторитетному имени» (Лихачев 1979. 70). 
Проповедь как жанр возникает одновременно с религиозным учением, будучи вторичной относительно Откровения: «Если Откровение - это информационный «первотолчок» религии, то проповедь - это начало жизни учения среди людей (в их сознании и религиозной коммуникации)» (Мечковская 1998. 150).

Цель проповеди как жанра религиозной коммуникации заключается в донесении божественного смысла до сознания людей. Адаптация первичного божественного смысла к возможностям человеческого разума может заключаться как в расширении первичного текста, к которому приводят толкования, повторы ключевых значений и прибавление к тексту новой убеждающей информации, так и в компрессии, когда во вторичном тексте оставляются только главные смыслы.

В анализируемых определениях выделяются следующие элементы коммуникативной ситуации, свойственные жанру проповеди: адресант священнослужитель, адресат - прихожане, верующие люди, хронотоп богослужение в храме, цель проповеди - назидание паствы.

Проповедь как жанр религиозного стиля функционирует не только в христианстве, анализ показывает наличие жанра проповеди и в других конфессиях, в частности, в исламе. При этом изучение лингвистикой жанра проповеди в других конфессиях пока не осуществлялось.

Используемый в настоящем исследовании коммуникативнопрагматический подход позволяет выявить жанрообразующие черты религиозных текстов на русском языке, существующих в разных конфессиях. Данный подход, являющийся частью одноименной научной макропарадигмы (Комарова 2012. 373), зародился в 60-х - начале 70-х годов ХХ-го века под влиянием теории речевых актов Д. Остина, Д.Р. Серля, 3. Вендлера, прагматических теорий значения П. Грайса, прагматических теорий 
референции Л. Минского, Д. Сёрла, П. Стросона и др. Термин прагматика, впервые введенный И. Кантом, получает широкое употребление после появления работы Ч.У. Морриса «Основания теории знаков» (1938): «с точки зрения прагматики, структура языка - это система поведения» (Моррис 1983. 65). Лингвистическая прагматика в общем виде изучает речевой акт (высказывание в его процессуальном аспекте как начальный уровень абстрагирования речевой деятельности человека (Остин 1986; Арутюнова 1988; Сёрл 2010) и компоненты речевого акта: коммуникативное взаимодействие говорящего и слушающего, происходящее в конкретной ситуации общения и обусловленное целеполаганием.

Теоретическим основанием коммуникативно-прагматического подхода является теория речевой деятельности Л.С. Выготского, А.Н. Леонтьева, А.А. Леонтьева, О.А Зимней и др., реализованная в интегративном коммуникативно-деятельностном подходе. Вопрос о существовании коммуникативно-прагматической лингвистики лишь ставится (Формановская 2002; Алефиренко 2009). Тем не менее лингвистика включает в сферу своих интересов все аспекты речевой деятельности, речевого взаимодействия, речевой коммуникации, а также текст и дискурс как «максимальные» (Арутюнова 1983. 3) объекты исследования, рассматривая их во взаимодействии с прагматическими факторами (Иссерс 2012).

Коммуникативно-прагматический подход имеет прямое отношение к тексту, так как анализ разнообразных условий коммуникации, условий порождения высказываний определенным образом связан с характером порождаемого текста, его языковыми особенностями и жанром. «Текст не может не быть прагматически определенным... Поэтому при исследовании текста нет такой области, которая не могла бы в том или ином смысле рассматриваться прагматически» (Медникова 1974. 191). Данный подход 
предполагает комплексный анализ текста, целью которого является выявление разноаспектных свойств текста, задачами, соответственно, - выявление и описание композиционных, семантических и прагматических свойств текста и способов его оформления (Комарова 2012. 445) в соответствии с функциональным стилем.

Обратимся к функционированию жанра проповеди в мусульманстве, рассмотрим ее коммуникативно-прагматические особенности. В мусульманстве, как и в христианстве, под проповедью понимается торжественная нравоучительная речь имама-хатыба, посвященная, как правило, какой-либо исламской религиозной или морально-этической проблеме.

Охарактеризуем основные элементы коммуникативного акта в проекции на мусульманскую проповедь.

Адресант мусульманской проповеди - имам-хатыб. Отметим, что имамхатыб в исламе не является священнослужителем, как это понимается в христианстве. Имам-хатыб - это «человек, который находится впереди. Так называюо и человека, который проводит коллективную молитву-намаз, и крупного мусульманского ученого, и халифа - главу мусульманского государства» (Али-заде 2007. 277).

Мусульманские богословы выделяют общие качества, присущие имамухатыбу в целом, и частные качества, отличающие его во время произнесения проповеди (Беюсов 2011). Остановимся на сказанном более подробно.

Имам-хатыб должен отличаться следующими качествами, носящими более общий характер: во-первых, обладать врожденными задатками, чтобы с удовольствием выполнять свои обязанности. Далее, необходимо владеть специальными знаниями, быть всесторонне образованным, начитанным человеком. Проповедник в исламе, обращаясь к прототексту Корана, цитирует его наизусть: «некоторые имам-хатыбы, у которых певучий голос прекрасная 
дикция, часто цитируют суры и аяты (чудо, коранические стихи) Корана, выдержки из хадисов. Уровень их образованности и степень владения чтениями Корана и его комментарием, а также искусное использование в проповедях хадисов (предание о словах и действиях пророка Мухаммада), создает у слушателей полное доверие к словам проповедника» (Каримов 1991. 35). Помимо Корана, проповедник обращается к современному материалу, включает в проповедь поучительные жизненные истории, касается актуальных социальных проблем, поучает аудиторию, каким должен быть современный мусульманин

Имам-хатыб должен отличаться силой воли, харизмой и высоконравственным поведением, чтобы служить образцом для аудитории: «О вы, которые уверовали! Почему вы говорите то, чего вы не делаете, и не выполняете своих обещаний?» (Сура «Ряды», 2 аят). Слова и дела должны соответствовать друг другу. Проповедник также должен быть искренним, что позволяет приблизиться к Богу: «А ведь им было велено лишь поклоняться Аллаху, служа ему искренне, как единобожники» (Сура «Ясное Знамение», 4 аят). Проповедник также должен обладать красноречием, следуя примеру Посланника Аллаха, который изъяснялся кратко и емко «джавамиг-альКалям» (Беюсов 2011)

Частные качества проповедника, способствующие успешному произнесению конкретной проповеди, относятся к области практической риторики. Важно владение техникой речи: сильный, красивый, звучный голос; выразительность речи, расстановка пауз, выделение значимых мест с помощью интонации; соблюдение культуры речи; умеренная жестикуляция. Особое внимание уделяется внешнему облику проповедника, который должен быть подобающе одет и выглядеть опрятно. Образцом служит Пророк Мухаммад, который дал прямые указания касательно внешнего вида: «О сыны Адама! Облекайтесь в свои украшения при каждой мечети» (Сура «Преграды», 31 аят) 
Таким образом, имам-хатыб должен обладать определенными духовными качествами, быть грамотным, коммуникабельным, активным и всесторонне образованным человеком, владеть приемами красноречия

Адресат мусульманской проповеди имеет ряд отличительных
особенностей. Мусульманская проповедь произносится в мечети и
предназначена для верующих мужчин, она является для них обязательным
элементом религиозной жизни: Совершение пятничного намаза в джамаате
(коллективная молитва) является обязанностью каждого мусульманина.
Свободными от посещения пятничных проповедей считаются только
«невольники, женщины, дети и больные» (Али-заде 2007 ).

Аудитория проповеди в мечети обычно мужская. Женщина в исламе занимает особое положение, ей не запрещается посещать мечеть, но рекомендуется молиться дома. В мусульманстве существует так называемая проповедь на дому, которую произносит как имам-хатыб, так и религиозно образованный человек, в том числе для женской аудитории - женщина.

Время и пространство. Мусульманская проповедь обычно произносится с минбара (Минбар - небольшое возвышение в мечети на которое поднимается имам для проведения хутбы (проповеди). После подъема имама на минбар все разговоры в мечети прекращаются и все внимание верующих концентрируется на проповеди имама (Али-заде 2007. 482).

Проповедь произносится имамом-хатибом в мечети при проведении пятничных и праздничных намазов. Если в православном богослужении проповедь произносится обычно либо во время богослужения сразу после чтения Евангелия, либо непосредственно сразу после богослужения, то мусульманская пятничная проповедь произносится перед богослужением (намазом - молитвой, совершаемой пять раз в день), «проповедь, читаемую только с минбаров мечети имам-хатыбами до начала пятничной и праздничной молитвы» (Каримов 1991. 25). 
Поясним, что пятница является для мусульман особым, праздничным днем, таким, как воскресенье у христиан и суббота у иудеев. Пятничные проповеди и пятничный намаз - это обязательность для каждого верующего, которая утверждена Священным Кораном.

Время и порядок проведения пятничной проповеди жестко определено: она произносится непосредственно перед намазами.

Последовательность действий проповедника определяется каноном, обязательным к соблюдению. Имам-хатыб всходит на минбар и поворачивается лицом к народу. В это время при полном молчании аудитории и проповедника муэдзин читает призыв на молитву. Далее имам-хатыб стоя читает обе части проповеди, в перерыве между которыми он садится.

Требования к адресату - собравшимся на молитву мусульманам - слушать проповедь в полном молчании, не отвлекаясь. Также нежелательным является совершение намаза во время проповеди.

Праздничные намазы совершаются утром, после восхода солнца, и проводятся в мечетях при большом скоплении народа. Они состоят из двух ракатов. После намаза читается праздничная проповедь. В отличие от пятничной проповеди, праздничная читается не до, а после намаза. Присутствие на них не обязательно, а желательно.

Цель проповедника - распространение ислама, истолкование божественных истин, назидание прихожан в соответствии с догматами. Мусульманские проповеди часто посвящены практическим вопросам, важным для человека в обыденной жизни. Проповедник в исламе затрагивает в проповеди обширный круг вопросов, зачастую имеющих индивидуальных характер: «В ряде мечетей имам-хатыб больше обращают внимания разъяснению культовой стороны религии; в других - разъяснению истории возникновения и места в жизни верующих аятов и сур (главы Корана) их Корана или хадисов» (Каримов 1991. 38). 
Как уже отмечалось выше, у мусульман есть обычай приглашать имамов к себе дом и другие места для участия в определенных жизненных событий. Обычно имамов приглашают к себе в дом, если не имеется возможности приехать в мечеть, либо необходимо прочесть молитву в кругу приглашенных гостей. Молитвы и проповеди могут читаться для различных жизненных событий: годовщина брака, рождения ребенка, имянаречение ребенка, смена имени на мусульманское, болезни, обряд захоронения, мероприятия и праздники.

Во время проповеди, произносимой перед женской аудиторией, имамхатыб рассматривает следующие темы: роль женщины в исламе, ролевые особенности жены, советы современным женам, также помогает найти правильное решение жизненно важных проблемных вопросов с помощью ислама, урегулировать спор и разногласия внутри семьи. Также для женщин в исламе действует исламская женская организация, основной целью которой является пропаганда ислама, обучение женщин, защита прав в семье и в обществе.

В исламе проповедь должна состоять из двух частей, первая из которых носит назидательный и воспитательный характер, а вторая включает обращение к Богу, мольбу для всех мусульман. В обеих частях обязательно содержатся канонические свидетельства о единстве Бога и посланнической миссии Мухаммада, а также приветствия пророку. Как отмечается, в средние века в проповедь был введен новый элемент: упоминание имен правящих халифов. Этот элемент был выражением политической благонадежности имамов и верующих.

Мусульманская проповедь традиционно произносилась на сакральном языке: «строго догматические элементы проповеди продолжали читать на арабском языке, потому что «хутба» (проповедь) входила в ритуальный комплекс богослужения (в нем нельзя было обо всем говорить, вопросы были 
строго регламентированы)» (Каримов 1991. 23). Сегодня мусульманская проповедь может произноситься как на народном языке (киргизском, татарском, узбекском, казахском и др.), так и на русском, особенно в регионах, где проживает больше количество русскоязычного населения.

Выводы. Изучение жанра проповеди, функционирующего на русском языке в различных традиционных конфессиях, является актуальным направлением современных лингвистических исследований. Коммуникативнопрагматический подход, используемый при анализе текстов, позволяет описать жанрообразующие черты, выявить как общее в структурных элементах коммуникативного акта (например, характеристика адресанта, коммуникативные требования, предъявляемые к нему; целеполагание назидание и разъяснение), так и отличительные особенности (например, особенности адресата в мусульманстве, отличительные черты пространственно-временной организации проповеди), свойственные жанру проповеди в конкретной конфессии. Изучение особенностей композиционнотематического структурирования исламской проповеди является перспективой дальнейших исследований.

\section{Литература}

1- Аверкий (Таушев), архиепископ. (2001). Руководство по гомилетике. М.: Издво «ПТБИ».

2- Али-заде А.А. (2007). Исламский энциклопедический словарь. М.: «Ансар».

3- Арутюнова Н.Д. (1983). Стратегия и тактика речевого поведения. Прагматические аспекты в изучении предложения и текста: сб. науч. тр. Киев: Изд-во «Штиинца».

4- Беюсов М. (2011). Каким должен быть имам-хатыб? Мусульмане России. http://www.dumrf.ru/islam/rites/2035 - дата обращения 04.04.2018.

5- Иванов Л.Ю. (2003). Проповедь. Культура русской речи: Энциклопедический словарь-справочник. М.: Флинта: Изд-во «Наука». 
6- Каримов И.А. (1991). Современная мусульманская проповедь (Социологический и религиоведческий аспекты): на материалах Узбекской ССР. Дисс. ... канд. философ. наук. М.

7- Лихачев Д.С. (1979). Поэтика древнерусской литературы. М.: Изд-во «Наука».

8- Матвеева Т.В. (2003). Проповедь. Учебный словарь: русский язык, культура речи, стилистика, риторика. М.: Флинта: Изд-во «Наука».

9- Медникова Э.М. (1974). Прагматический аспект текста. Лингвитика текста: Материалы научной конференции. М

10- Мечковская Н. Б. (1998). Язык и религия. М.: Изд-во «Агентство ФАИР».

11- Моррис Ч.У. (1983). Основания теории знаков. Семиотика. М.: Изд-во «Радуга».

12- Прохватилова О.А. (1999). Православная проповедь и молитва как феномен современной зөучащей речи. Волгоград: Изд-во Волгоградского государственного университета.

\section{Bibliography}

1- Averkij (Taushev), arhiepiskop. (2001). Rukovodstvo po gomiletike. M.: Izd-vo «PSTBI».

2- Ali-zade A.A. (2007). Islamskij jenciklopedicheskij slovar'. M.: «Ansar».

3- Arutjunova N.D. (1983). Strategija $i$ taktika rechevogo povedenija. Pragmaticheskie aspekty $v$ izuchenii predlozhenija i teksta: sb. nauch. tr. Kiev: Izdvo «Shtiinca».

4- Bejusov M. (2011). Kakim dolzhen byt' imam-hatyb? Musul'mane Rossii. http://www.dumrf.ru/islam/rites/2035 - data obrashhenija 04.04.2018.

5- Ivanov L.Ju. (2003). Propoved'. Kul'tura russkoj rechi: Jenciklopedicheskij slovar'spravochnik. M.: Flinta: Izd-vo «Nauka».

6- Karimov I.A. (1991). Sovremennaja musul'manskaja propoved' (Sociologicheskij i religiovedcheskij aspekty): na materialah Uzbekskoj SSR. Diss. ... kand. filosof. nauk. M.

7- Lihachev D.S. (1979). Pojetika drevnerusskoj literatury. M.: Izd-vo «Nauka».

8- Matveeva T.V. (2003). Propoved'. Uchebnyj slovar': russkij jazyk, kul'tura rechi, stilistika, ritorika. M.: Flinta: Izd-vo «Nauka».

9- Mednikova Je.M. (1974). Pragmaticheskij aspekt teksta. Lingvistika teksta. Materialy nauchnoj konferencii. M.

10- Mechkovskaja N.B. (1998). Jazyk i religija. M.: Izd-vo «Agentstvo FAIR». 
11- Morris Ch.U. (1983). Osnovanija teorii znakov. Semiotika. M.: Izd-vo «Raduga».

12- Prohvatilova O.A. (1999). Pravoslavnaja propoved' $i$ molitva kak fenomen sovremennoj zvuchashhej rechi. Volgograd: Izd-vo Volgogradskogo gosudarstvennogo universiteta.

\section{HOW TO CITE THIS ARTICLE}

Ицкович, Т., \& Туголбайкызы, А. (2019). Muslim Sermons

in Russian: Communicative and Pragmatic Aspect.

Issledovatel'skiy Zhurnal Russkogo Yazyka I Literatury, 7(2),

47-62.

DOI: 10.29252 /iarll.13.2.47

URL: http://www.journaliarll.ir/index.php/iarll/article/view/79 


\section{خطبههاى اسلامى به زبان روسى: بُعد ارتباطى و كاربردى}

$$
\begin{aligned}
& \text { تاتيانا ويكتوروونا ايتسكاويج' }
\end{aligned}
$$

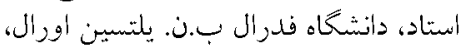

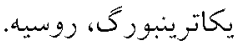

$$
\begin{aligned}
& \text { آيجمال تو كالباى كيزى ' } \\
& \text { كارشناس ارشد زبان و ادبيات روسى، دانشكاه فدرال بـن. يلتسين أورال، } \\
& \text { يكاترينبورگ، روسيه. } \\
& \text { (تاريخ دريافت: فوريه 19+T: تاريخ بذيرش: زوئن 19.19) }
\end{aligned}
$$

هدف يزوهش حاضر بررسى زانر خطبه اسلامى به زبان روسى است. بيشتر مطالعـات روسيـا

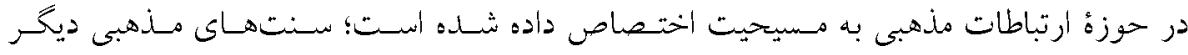

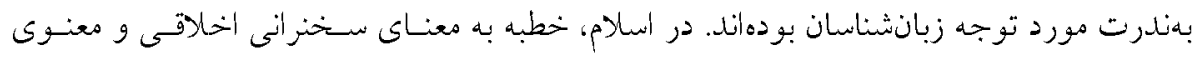

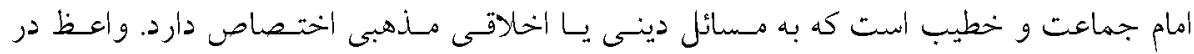

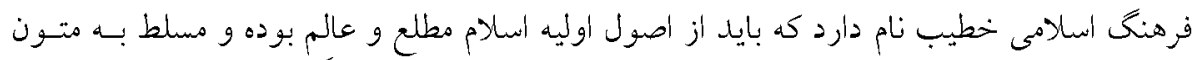

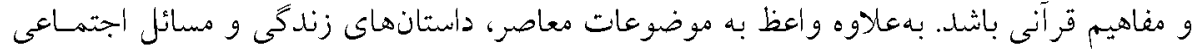

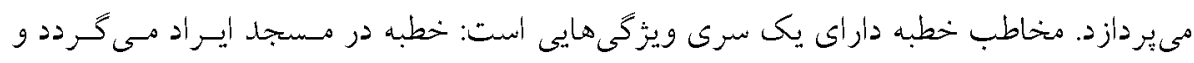

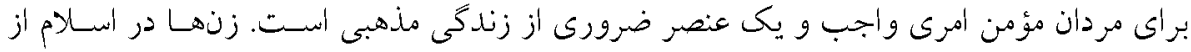

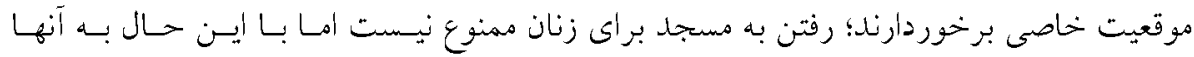

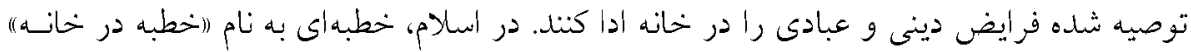

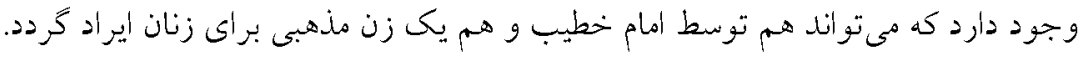
وازَّان كليدى: سبكى كَتارى دينى و مذهبى، دين اسلام، خطبه، بُعلد ارتباطى و كاربردى، خطيب،

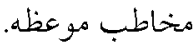

